LICENÇA CC BY: Artigo distribuído sob os termos Creative Commons, permite uso e distribuição irrestrita em qualquer meio desde que o autor credite a fonte original.

\section{GLOBAL COMPETENCE BEGINS IN PRESCHOOL: AN INVESTIGATION OF HOW TO NURTURE EMPATHY IN YOUNG CHILDREN}

COMPETÊNCIA GLOBAL COMEÇA NA PRÉ-ESCOLA: UMA INVESTIGAÇÃO DE COMO ESTIMULAR A EMPATIA EM CRIANÇAS

PEQUENAS

COMPETENCIA GLOBAL COMIENZA EN LA PRE-ESCUELA: UNA INVESTIGACIÓN DE COMO ESTIMULAR LA EMPATÍA EN NIÑOS

PEQUEÑOS.

Daniela Fenu Foerch ${ }^{1}$

${ }^{1}$ Florida International University, Miami, Florida, United States.

Article received on: 08/28/2020

Approved on: 10/22/2020

Abstract: This collaborative action research study examines the effects of the implementation of Global Thinking Routines and Thinking Routines on the development of empathy, a global competent disposition, in preschool children. The study investigates how students are able to identify their emotions and the emotions of others, and consequently, how they attempt to manage those emotions. The Emotion Cards pre-test was applied to a sample of 44 preschoolers, who then participated in classroom learning experiences, including Visible Thinking and Global Thinking routines. Afterwards, the Emotion Cards post-test was applied. The purpose was to examine the implementation of these routines and their impact on preschoolers' development of empathy, a component of Emotional Intelligence and global competence. A collaborative action research study approach was used, with qualitative data in the form of documentation, which included videos, pictures, notes, parents' feedback, kindergarten teacher's feedback, ongoing study group discussions and reflections with the researcher, the teachers and atelierista. Quantitative data with descriptive statistics were also collected, comparing the quantitative pre- and postdata. The main findings indicate that (1) preschoolers demonstrated growth in the development of empathy and (2) teachers also demonstrated the development of empathy. The findings also indicated (3) a possible change in the traditional discipline system commonly implemented in today's classroom, with a more innovative and constructive method that could potentially decrease negative behaviors in children with behavioral challenges.

Keywords: global competence; empathy; emotional Intelligence; perspectives; Thinking Routines; Global Thinking Routines; Habits of Mind; qualitative research; teacher reflection; classroom implications; grounded theory; action research. 
Resumo: Este estudo de pesquisa-ação colaborativa examinou os efeitos da implantação das Rotinas de Pensamento Global e Rotinas de Pensamento no desenvolvimento da empatia, um componente de Competência Global, em crianças pré-escolares. O estudo investiga como estudantes conseguem identificar as próprias emoções e as emoções dos outros e, consequentemente, como buscam lidar com elas. O pre-test Cartões das emoções foi aplicado em uma amostra de 44 pré-escolares, que depois participaram de experiências de aprendizagem em sala de aula, incluindo Pensamento Visível e rotinas de Pensamento Global. Posteriormente, foi aplicado o pós-test Cartões das emoções. O objetivo era examinar a implementação dessas rotinas e seus impactos no desenvolvimento da empatia em pré-escolares, um componente de Inteligência Emocional e de Competência Global. Foi utilizada como abordagem de estudo a pesquisa-ação colaborativa, com documentação de dados quantitativos, que incluem vídeos, fotos, anotações, parecer dos pais, parecer do professor da pré-escola, discussões e reflexões no grupo de estudos e reflexões com o pesquisador, professores e atelierista. Foram também coletados dados quantitativos com estatística descritiva e foram comparados os dados pré e pós-quantitativos. Os principais resultados indicam que (1) os pré-escolares demonstraram aumento no desenvolvimento da empatia e (2) os professores também demonstraram o desenvolvimento da empatia. Os resultados também indicaram (3) uma possibilidade para mudança no sistema disciplinar tradicional comumente implementado nas salas de aula de hoje, com um método mais inovador e construtivo que poderia diminuir os comportamentos negativos em crianças com desafios comportamentais.

Palavras-chave: competência global; empatia; inteligência emocional; perspectivas; rotinas de pensamento; rotinas de pensamento global; hábitos mentais; pesquisa qualitativa; reflexão do professor; implicações em sala de aula; teoria fundamentada; pesquisa-ação.

Resumen: Este estudio de investigación acción colaborativa, examinó los efectos de la implementación de las Rutinas de Pensamiento Global y Rutinas de Pensamiento en el desarrollo de la empatía, un componente de Competencia Global, en niños pre-escolares. El estudio investiga como estudiantes consiguen identificar las propias emociones y las emociones de los otros y, consecuentemente, como se relacionan con ellas. El pre-test Tarjetas de emociones fue aplicado a una muestra de 44 pre-escolares, que después participaron de experiencias de aprendizaje en clase, incluyendo Pensamiento Visible y rutinas de Pensamiento Global. Posteriormente, fue aplicado el pos-test Tarjetas de emociones. El objetivo era examinar la implementación de esas rutinas y sus impactos en el desarrollo de empatía en pre-escolares, un componente de Inteligencia Emocional y de Competencia Global. Fue utilizado como abordaje de estudio la investigación acción colaborativa, con documentos de datos cuantitativos, que incluyen videos, fotos, anotaciones, parecer de los padres, parecer del profesor de la preescuela, discusiones y reflexiones en el grupo de estudios y reflexiones con el investigador, profesores y profesores de taller. Fueron también recolectados datos cuantitativos con estatística descriptiva y fueron comparados los datos pre y pos cuantitativos. Los principales resultados indican que (1) los pre-escolares demuestran aumento en el desarrollo de la empatía y (2) los profesores también demostraron el desarrollo de la empatía. Los resultados también indicaron (3) una posibilidad de cambio en el sistema disciplinar tradicional comumente implementado en las clases de hoy, con un método más innovador y constructivo que podría disminuir los comportamientos negativos en niños con desafíos de conducta.

Palabras clave: competencia global; empatía; inteligencia emocional; perspectivas; Rutinas de pensamiento; Rutinas de pensamiento global; Hábitos mentales; investigación cualitativa; reflexión docente; implicaciones en el aula; teoría fundamentada; investigación para la Acción. 


\section{INTRODUCTION TO THE THEORETICAL APPROACH}

The purpose of this study is to investigate how implementing an approach that fosters emotional literacy, Visible Thinking and Global thinking routines nurtures empathy in young children, a component of global competence. This study was developed after a professional development session at a preschool in Miami, Florida, between the researcher, the director of the preschool, four preschool teachers, and the atelierista (see glossary). Emotional Intelligence and empathy are major components internalized by global competent individuals (Goleman, 1995, Boix-Mansilla \& Jackson, 2011, Costa \& Kallick, 2000) and empower children to become catalysts of our world. Global competent students are those who are able to empathize with other individuals who are different from themselves, and portray different views and awareness about issues of global significance. There has been much discussion about nurturing global competence in students, but very little has been discussed in preschool settings (Boix-Mansilla \& Jackson, 2011; Darling-Hammond, L., 2010). This study furthers understanding of how to nurture global competence, Emotional Intelligence and in particular, empathy in young children, the latter being one of the main components of the former two. This collaborative action research study examines the effects of the implementation of Global Thinking Routines and Thinking Routines on preschoolers' development of empathy, a global competent disposition.

\section{LITERATURE REVIEW}

\section{Defining Global Competence}

According to Veronica Boix-Mansilla and Anthony Jackson (2011), global competence is the "capacity and disposition to understand and act on issues of global significance" (p.13). Boix-Mansilla continues by emphasizing that today's educational mission and methods of preparing our students are very different from those we experienced growing up. The world today is vastly different from the one we lived in, due to the rapid and sweeping changes that have occurred in past fifteen years. Society has changed. Our population and encounters have changed. Our economy has changed. Nevertheless, schools still focus on preparing our students for academics, leaving behind the fundamental notion of developing global competent citizens (Darling-Hammond, L., 2010; Salovey, P. Brackett, M., \& Mayer, J. 2004).

Boix-Masilla and Jackson (2011) define four capacities of global competence: (1) investigating the world, (2) recognizing perspectives, (3) communicating ideas, and (4) taking action. This framework recognizes the need for students to investigate global issues that are outside of their immediate environment; a topic that is not completely alien to them. It also promotes awareness of global issues and the recognition of different perspectives on the same 
issue. Who are the stakeholders involved in this issue? And what are their views? Students should be invited to step inside the worlds of different stakeholders and attempt to feel how they feel in reference to a particular issue. Then, students should communicate these ideas and perspectives, identify, and discuss the differences with diverse audiences. Lastly, once all the perspectives and concerns are identified, students should attempt to take action to find the best possible solution for all stakeholders (Boix-Mansilla and Anthony Jackson, 2011). Recognizing perspectives, empathy and its process, is one of the goals of this collaborative action research study.

\section{Defining EMOtional INTELligence}

The topic of Emotional Intelligence (EI) was first introduced by Salovey \& Mayer in 1990 and became popular with Daniel Goleman's (1995) theory of Emotional Intelligence (EI). Salovey and Mayer's (1995) model emphasized four specific domains of El, which include "the ability to 1) perceive emotions in one's self and others, 2) use emotions to facilitate thinking, 3 ) understand emotional knowledge, and 4) regulate emotions in one's self and others" (Pellitteri, Dealy, Fasano \& Kugler, 2006, p. 156). To accurately perceive one's emotions and the emotions of others means paying close attention to nonverbal cues, such as facial expressions and tone of voice, and using these cues to determine the affective states of others. To facilitate thinking refers to being able to assess the affective and generate emotions that guide problem solving and decision-making. Understanding emotional knowledge involves understanding emotional expressions, such as frustration. Regulating emotions means being able to consciously maintain and tolerate an emotional state and to reflectively moderate the emotions based on their adaptiveness, and influencing the emotional state of others.

Goleman's Theory of El revealed Emotional Intelligence - the combination of interpersonal and intrapersonal intelligence is one of the most significant factors that predict later success in life. Goleman's theory fosters four domains of El: self-awareness, self-management, social awareness, and relationship management (Goleman, 2002). Numerous research studies have measured the above domains using the Devereux Early Childhood Assessment (DECA), which is a well-known assessment tool used to measure social and emotional development in young children (Brinkman, Wigent \& Tomac, 2007; LeBuffe, 1998; 2002). Self-awareness is the individual's ability to recognize and name emotions; self-management is the individual's ability to manage their emotions; social-awareness is the individual's ability to read people and groups precisely; and relationship management is the individual's ability to manage their relationships. Self-Awareness is the ability to know one's own emotions (Goleman, 2002). For instance, often a young child will throw a tantrum because he is tired, confused, unhappy, frustrated or embarrassed. The young child is unable to understand how he is feeling, or to name that feeling. Therefore, Self-Awareness is one of the main components of global competency and empathy. 
Once individuals are aware of how they feel, and can actually name those feelings, they will be able to manage those emotions. Self-Management is the next domain fostered by Goleman (Goleman, 2002). It encompasses five competencies: emotional management, trustworthiness, conscientiousness, adaptability, and initiative competence. Emotional management is the individual's ability to manage their own emotions. For instance, individuals who are in a stressful situation are able to control their internal states and impulses. Trustworthiness, another SelfManagement competence, is present in individuals who can make their values and feelings clearly known, and are consistent in the way they use them (Goleman, 2002). Conscientiousness, the third Self-Management competence, consists of being rigorous, responsible, and selfdisciplined in performing duties. Individuals usually show good citizenship because they act in the way they ought to. They know the difference between right and wrong. Additionally, adaptability is one of the competencies displayed in individuals who are able to adjust to different types of situations, and to free themselves from old theories and adopt new ones without fear. These individuals also try to find new ideas and strategies to achieve the desired outcomes or attain specific results. Initiative is the final competence of Self-Management. Individuals with initiative will embark on a project before being asked.

Social awareness is Goleman's third domain of El. Social awareness is the ability to read people and groups accurately (Goleman, 2002). This domain contains two competencies: empathy and service orientation. Empathy enables individuals to be aware of other people's feelings. An empathetic person is capable of sensing verbal, but even more importantly, nonverbal cues that show how other people feel. Service orientation, the second component of Social Awareness, is the individual's ability to identify other people's needs and to attempt to help them meet those needs, without necessarily receiving anything in return.

Relationship management is Goleman's last domain of El and is the individual's ability to manage their relationships (Goleman, 2002). Having good social skills is one of the factors that enable individuals to manage their relationships positively. These individuals are not just leaders themselves, but they also help others become leaders in managing relationships.

Goleman (1995) argues that an individual's ability to identify, control and manage his or her emotions is a great predictor of future success in life. Goleman's theory of El also revealed that the Intelligence Quotient [IQ], in itself, does not necessarily predict a child's future success in life. Rather, El - the combination of interpersonal and intrapersonal intelligences - is one of the most significant predictors of later success in life. Numerous research studies have shown that young children and adults with high regular IQ levels were not as emotionally healthy or as successful in life as those with high El levels (Bar-On, 2000; Freedman, Ghini, \& Fiedeldey-van Dijk, 2008; Friedman \& Everett, 2008; Gardner, 2006; Goleman, 1995; Salovey \& Mayer, 2004; Vaillant, 1995). Pellitteri, Dealy, Fasano and Kugler (2006) concur with this finding, in that students with high El are better able to solve problems in the final set of tasks, after struggling with difficult ones, which may mean that they have better perseverance when faced with frustrating situations. 
In helping students to develop social and emotional skills, Heydenbeck and Heydenbeck (2007) postulate that in El programs, negative feelings are not suppressed, but instead, students are coached on how to use opportunities to develop a deeper understanding of themselves and others, and how to effectively process negative emotions. Usually, in these programs, the students benefit from a healthier and better-adjusted lifestyle. Preschool teachers often face very difficult challenges in the classroom. While children can sometimes demonstrate difficult behavior that is developmentally appropriate and can be shaped by guidance and communication, there are others whose behavior becomes such a persistent problem that it leads to expulsion from preschool programs (Fox \& Harper-Lentini, 2006).

\section{DEFINING EMPATHY}

Daniel Goleman defines three types of empathy: "cognitive" empathy, emotional empathy and compassionate empathy or empathic concern (Goleman, 2006). Cognitive empathy is the ability to identify verbal and non-verbal emotions in others. This disposition could be negative because some individuals might use this knowledge to manipulate others to get what he or she wants resulting in harming the other individuals to achieve their own goals. Cognitive empathy could be a positive disposition if we also have and demonstrate emotional empathy. Emotional empathy is being able to emotionally connect with others when sharing or displaying emotions. Basically, making them feel that we know how they feel because we might have experienced those feelings once even if due to different reasons. Compassionate empathy or empathic concern is defined by Goleman as the dispositions internalized and displayed by individuals who desire and offer to take action to solve the issue and help others feel better without asking anything in return (Goleman, 2006).

\section{Defining Visible ThINKING Routines}

Visible Thinking routines are an integral part of the Visible Thinking Approach developed by Ron Ritchhart, the Principal Investigator of the Visible Thinking Approach Project at Harvard University in Boston, Massachusetts (Ritchhart, R., Church, M., Morrison, K., 2011; Ritchhart, 2012). The purpose of this approach is to cultivate a culture of thinking in the classroom, in which thinking is valued, shared and made visible. The routines are mini strategies that can be easily implemented in the classrooms to nurture critical thinking. For the purpose of this study, the researcher invited the participating teachers to use the following routines: See/ Think/Wonder routine, Step Inside routine, the Chalk-Talk routine, and the What makes you say that? (Ritchhart, R., Church, M., Morrison, K., 2011; Ritchhart, 2012).

The See/Think/Wonder routine is used in the classroom when in-depth observations and analysis of object, videos or phenomena are presented to individuals. It first invites students to share what the "see" and only what they see, without giving any interpretation. After students 
have shared what they have seen, they are invited to share what they "think" about the observed object or phenomena. After the interpretation phase, the individuals are invited to share what they "wonder", or what questions they have about what they have observed (Ritchhart, 2012).

The Step Inside routine requires individuals to step inside another person and attempt to view the world through their lenses. It encourages perspective taking (Ritchhart, 2012).

The Chalk-Talk routine is used in the classroom to analyze an object, video or phenomenon. It involves placing an objector picture, for example, in the center of a white board or chart paper, and then having a small group of individuals write or draw around that object. As they write or draw, individuals can jot down anything that comes to mind, and also make connections to others' thoughts or ideas (Ritchhart, 2012).

The What makes you say that? Routine is used when individuals are invited to provide justification of their answers. Basically, they are asked to share how they know that the answer provided is true and/or valid (Ritchhart, 2012).

\section{Defining Global Thinking Routines}

Global Thinking routines are mini routines that foster global competence. They help an individual to analyze issue of global significance, through in depth investigation and perspective taking. The Global Thinking routines used in this research study are the Point-of-View routine and the 3 Ys (Boix-Mansilla \& Jackson, 2011).

The Point-of-View global thinking routine asks individuals to first identify all the protagonists involved in an issue or scenario of global significance. Second, participants are asked to select one of those individuals. They are then encouraged to step inside that person and attempt to see the world through their lenses, using the pronoun "I". They then attempt to narrate the how they feel, how they would act, and what they are thinking, giving their reasons. The last step of this global thinking routine is to step outside of that person and be themselves again. During this phase, the individuals attempt to investigate a possible solution, keeping in mind the perspective of the character they selected.

The 3 Ys global thinking routine invites individuals to travel from a personal, to a local to a more global dimension (Boix-Mansilla \& Jackson, 2011). This routine invites learners to examine an issue by analyzing the relevance of the issue from different perspectives and backgrounds.

\section{DefinIng Habits OF MIND}

The optimal development of empathy requires mastering specific thinking dispositions. According to Arthur Costa and Bena Kallick, there are sixteen Habits of Mind, also defined as intelligent behaviors, that individuals use when attempting to solve a problem where the solution to that problem is not evident. These thinking dispositions are listed as Persisting, 
Thinking and communicating with clarity and precision, Managing impulsivity, Gathering data through all the senses, Listening with understanding and empathy, Creating, imagining, innovating, Thinking flexibly, Responding with wonderment and awe, Thinking about thinking (metacognition), Taking responsible risks, Striving for accuracy, Finding humor, Questioning and posing problems, Thinking interdependently, Applying past knowledge to new situations, and Remaining open to continuous learning (Costa \& Kallick, 2000). For the purpose of this research study, the researcher selected the following Habits of Mind: Managing impulsivity, Thinking flexibly, Thinking about thinking (metacognition), Thinking interdependently, and Listening with understanding and empathy. Preschoolers were invited to learn how to manage their impulsivity when feeling certain emotions, whether pleasant or unpleasant. They were encouraged to find alternative and appropriate ways to deal with those emotions. For instance, when angry, they had to attempt to stop and think, and calm themselves down before reacting negatively to the stimulus that had triggered the strong emotions. Preschoolers were also invited to think flexibly and interdependently, by being open minded and working as a group to find a solution to an issue of global significance. Another important Habit of Mind that was used with the preschoolers during the research study was Metacognition, which entails having strategies to solve a problem. For this research, they had to attempt to find strategies that would help themselves and/or others feel better, without asking for anything in return. The last Habit of Mind proposed to the preschoolers was Listening with Understanding and Empathy. This disposition helped them to listen very carefully to others, not only with their ears but with all of their senses, paying close attention to verbal and non-verbal cues.

\section{RESEARCH METHOD}

A mix method approach was used, with quantitative and qualitative data. A combination of collaborative action research and grounded theory research designs were used to investigate how to nurture empathy in young children (Creswell, 2007). Collaborative action research involves co-participants during the research process. This particular study involved a university professor, four preschool teachers and an atelierista, an on-site artist who assists the children and teachers throughout the processes of learning and the development of documentation. Grounded theory was used within an action research cycle. Action research was embedded in the grounded theory design because the researcher, the teachers and the atelierista were active participants in this research from the beginning. Collaborative action research includes several benefits. The researcher has the opportunity to be fully engaged and immersed in the research process in the classroom. The teachers and the atelierista have the opportunity to be part of the process, and to fully collaborate in a research study in which they are the main protagonists along with their children. The research question that guided this study was: How will the implementation of children's literature, Global Thinking Routines and Thinking Routines affect preschoolers' development of empathy, a global competent disposition? 
This research study was conducted at a Reggio Emilia-inspired educational learning center in Miami, Florida.

The study participants consisted of preschoolers $(n=44)$, preschool teachers $(n=4)$, an atelierista $(n=1)$ and the researcher $(n=1)$. All the participants were purposefully selected. All the teachers had Associate Arts degrees or higher degrees in education. They were all female, and the majority had an average of ten years of experience. The atelierista had a Bachelor of Arts degree and extensive experience in the Reggio Emilia philosophy. The researcher shared her research topic interest with the teachers and the atelierista during a visit to the learning center, after which the teachers shared their concerns about two of their students in the classroom who were expressing challenging behaviors and were interrupting the flow of the classroom. After an exchange of conversations, the teachers and atelierista agreed to participate in the collaborative action research.

\section{PROCEDURES/INTERVENTION}

During this study, teachers and students received the following intervention:

\section{Workshops and Study Groups fOr teachers}

A total of six professional development workshops were provided to the teachers participating in this study, over a period of six months during the fall and spring semesters. The content of the workshops focused on the connection between the brain and the emotions, global competence, empathy, visible thinking approach, global thinking routines, and reflective practices. In addition to the workshops, ongoing study groups were scheduled with the teachers and atelierista, to reflect and discuss the effects of using the routines in order to develop empathy in young children (Blythe, T., Allen, D., \& Powell, B. S., 2008). Study groups for the teachers took place once or twice a month during the children's naptime. The purpose was to examine the use of children's literature in combination with these routines, and their impact on the preschoolers' development of empathy, a component of Emotional Intelligence and global competence.

\section{Emotion Cards pre- And post-assessment for Children}

This assessment is an effective and simple tool to identify and perceive emotions portrayed on cards. The cards are used to assess Emotional Knowledge, and include emotions like angry/mad, lonely, tired, happy, sad, frustrated, proud, disgusted, and surprised. 


\section{DATA COLLECTION}

The Emotion Cards pre-test was the first quantitative assessment administered to the children, in order to investigate their awareness of emotions. The same assessment was administered to the children at the end of the study to investigate whether their knowledge of emotions had increased. Additionally, throughout the entire study, data was gathered from various other sources, such as documents, artifacts, videos, pictures, teacher's reflections, and the children's dialogue, all pertaining to the purpose of this study. The final data collection action was an interview, conducted a year later, with the kindergarten teachers who taught some of the students included in this study. Approximately ten four-year-olds attended the kindergarten at an elementary charter school located next to the learning center where this study was conducted. When we interviewed their kindergarten teacher, she shared with the researcher that the children who had been involved in this research study were different from the rest of the group. She explained that they were more aware of the individuals around them. For instance, when all children had to work on a group project and were required to work together and draw on a single, large sheet of paper placed on the floor, the research students either made room for other children to sit or provided them with tools they were looking for to complete or participate in the project, without being asked to do so by the other children. Basically, these children were able to "read" non-verbal cues and provide assistance to meet their needs. As a result of this increased awareness, the teacher also shared that she had witnessed very few behavioral incidents in the classroom because of how adaptable and helpful those ten children were (Gangotena, V. personal communication, December 15, 2015).

\section{ANALYSIS}

\section{Quantitative Data Analysis}

The research was evaluated using the following qualitative data analysis: (1) the paired t-test was conducted, to investigate any differences between the means of the results of the Emotion Cards pre- and post-assessment. The paired-samples t-test was conducted to compare pre- and post-test emotion knowledge results in the three- and four-year-olds. The results indicated that there was a significant difference in the pre-test scores for the four-yearolds $(M=3.0, S D=.91)$ and post-test scores $(M=4.7, S D=1.3)$ after the intervention; $t(17)=-7.2$, $p=.004$. However, there was no significant difference in the pre-test scores for the threeyear-olds $(M=1.8, S D=1.2)$ and the post-test scores $(M=4.0, S D=1.1)$ after the intervention; $t$ $(14)=7.4, p=0.059$. 
Table I - Paired t-test for Emotion Cards

Descriptive Statistics and t-test Results for Emotion Knowledge

\begin{tabular}{|c|c|c|c|c|c|c|c|c|c|c|}
\hline & \multicolumn{2}{|c|}{ Pretest } & & \multicolumn{2}{|c|}{ Posttest } & & $95 \%$ Cl for Mean & & & \\
\cline { 1 - 4 } Outcome & $\mathrm{M}$ & $\mathrm{SD}$ & & $\mathrm{M}$ & $\mathrm{SD}$ & $\mathrm{n}$ & Difference & & $\mathrm{t}$ & $\mathrm{df}$ \\
\hline $\begin{array}{c}\text { Emotion } \\
\text { Cards 4YO }\end{array}$ & 3.0 & .91 & & 4.7 & 1.3 & 17 & $-2.22,-1.21$ & & $-7.43^{*}$ & 14 \\
\hline $\begin{array}{c}\text { Emotion } \\
\text { Cards 3YO }\end{array}$ & 1.8 & 1.2 & & 4.0 & 1.1 & 14 & $-2.83,-1.56$ & & -7.17 & 17 \\
\hline
\end{tabular}

$* p<.000$.

\section{Qualitative Data Analysis}

In order to examine how to nurture empathy in young children, this study implemented a combination of ground theory coding and analysis, within a collaborative action research.

\section{GROUNDED THEORY CODING AND ANALYSIS.}

The data collected for this study were transcribed and entered into the qualitative software program NVivo, version 11.1. The grounded theory design utilized in this study is the deductive design, with the purpose of systematically identifying all emerging themes in the data. Strauss and Corbin (1998) theory aimed to construct new theories when redeveloped this form of analysis, which was initially created by Glaser and Stauss (1967). The researcher used a similar coding process to examine themes around the use of Visible Thinking and Global Thinking routines to nurture empathy in young children. A deductive grounded theory approach was used to analyze the data, seeking to systematically identify all emerging themes in the data under examination. For the purpose of this study, the researcher used the sequential coding utilized by Harry et al. (2005), which includes the following phases of coding: open coding, focus coding, conceptual categories and thematic coding (Creswell, 2012).

\section{OPEN CODING}

All the transcriptions were chronologically analyzed during the open coding phase (Harry et al., 2005). These reflected an on-going analysis of participants' experiences and reflections about how empathy was nurtured in young children. During the data collection and analysis, descriptive codes were created, based on the experiences about empathy. The descriptive codes 
were suggested, which were concretely and specifically linked to the participants' experiences (Strauss \& Corbin, 1998). An example of open coding from the data is that the utterance "we need to tell people how we feel!" was coded as self-awareness. Another is that "we can play safely and not hurt each other", was coded as social-awareness. The use of the exact participant quotes is an example of "N-vivo", which refers to the optimal description of the representing experience or concept (Strauss \& Corbin, 1998). An example of "N-vivo" codes retrieved from the data collected is "we now have a better understanding how essential it is to be sensitive and open towards others, to feel, to understand, to go beyond to help others grow, and to acknowledge our own growth!" The first round of open coding resulted in a total of 69 codes for the data under examination. After reviewing these codes, they were condensed to 10 .

\section{FOCUS CODING}

Focused codes were developed after a thorough comparison process in which the codes were grouped according to their similarities (Charmaz, 2016). The purpose of the data was to investigate whether the use of visible thinking and global thinking routines nurtured global competence in young children, with a particular focus on empathy. Therefore, focusing the coding resulted in codes that reflected the participants' reactions and reflections, and the development of the components of empathy: self-awareness, self-management, socialawareness, modeling as essential, teacher development of own empathy, brain and emotions, empathy match, empathy verbal, empathy non-verbal, initial teacher concerns.

Conceptual categories. Through a process of continual comparison, conceptual groups of categories were created based on similarities (Strauss \& Corbin, 1998). The entries differ within each categorical group of open codes, but confirmed similar meaning. For instance, the open codes "empathy verbal" and "empathy non-verbal" belonged to the same category, which was labeled social-awareness. When the conceptual coding process was complete, a total of 6 conceptual categories remained.

Thematic coding. During the thematic coding, conceptual categories are analyzed by property and dimension to create thematic statements, with the purpose of investigating relationships between concepts (Strauss \& Corbin, 1998). For example, after analyzing the documents and videos, an emerging theme was "modeling as essential". In order to nurture empathy in young children, the teachers had to model how to be empathetic. There was a close correlation between modeling empathy and how this led to "teachers development of their own empathy". Through deep reflection, the teachers shared that this was one of the most important factors in developing young children's empathy. After examining the relationship between the conceptual categories and codes derived from the themes, five themes remained: self-awareness, self-management, empathy and teacher development of empathy. 
Table 2 - The research question, themes, conceptual categories and selection of open codes

Research Question: How does the implementation of the literature, Global Thinking Routines and Thinking Routines affect preschoolers' development of empathy, a global competent disposition?

Summative Statement: During the research period, the teachers applied children's books, visible thinking routines, and global thinking routines to develop and nurture empathy, one of the global competence dispositions, in young children. This led to the development of empathy in young children and deeper reflection on the part of teachers, on their own personal practices, eventually resulting in the development of empathy in the teachers.

Theme: Responses/actions and reflections to experiences that foster empathy leading to generalization.

\begin{tabular}{|c|c|c|c|c|}
\hline $\begin{array}{l}\text { Conceptual Cat- } \\
\text { egory: } \\
\text { Self-awareness }\end{array}$ & $\begin{array}{l}\text { Conceptual Cat- } \\
\text { egory: } \\
\text { Self-management }\end{array}$ & $\begin{array}{l}\text { Conceptual Cat- } \\
\text { egory: } \\
\text { Social-awareness }\end{array}$ & $\begin{array}{l}\text { Conceptual Cat- } \\
\text { egory: } \\
\text { Teacher Devel- } \\
\text { opment of Own } \\
\text { Empathy }\end{array}$ & $\begin{array}{l}\text { Conceptual Cat- } \\
\text { egory: } \\
\text { Modeling as Es- } \\
\text { sential }\end{array}$ \\
\hline
\end{tabular}




\begin{tabular}{|c|c|c|c|c|}
\hline 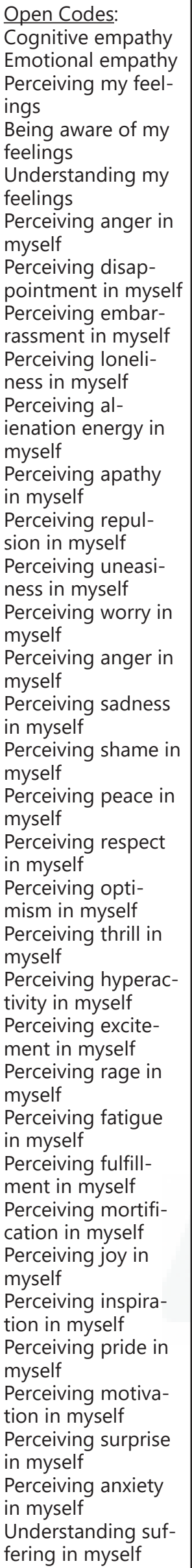 & $\begin{array}{l}\text { Open Codes: } \\
\text { Taking action to help } \\
\text { myself } \\
\text { Managing frustration } \\
\text { in myself }\end{array}$ & $\begin{array}{l}\text { Open Codes: } \\
\text { Compassionate em- } \\
\text { pathy } \\
\text { Perceiving anger in } \\
\text { others } \\
\text { Perceiving disappoint- } \\
\text { ment in others } \\
\text { Perceiving embarrass- } \\
\text { ment in others } \\
\text { Perceiving loneliness } \\
\text { in others } \\
\text { Perceiving alienation } \\
\text { energy in others } \\
\text { Perceiving apathy in } \\
\text { others } \\
\text { Perceiving repulsion } \\
\text { in others } \\
\text { Perceiving uneasiness } \\
\text { in others } \\
\text { Perceiving worry in } \\
\text { others } \\
\text { Perceiving anger in } \\
\text { others } \\
\text { Perceiving sadness in } \\
\text { others } \\
\text { Perceiving shame in } \\
\text { others } \\
\text { Perceiving peace in } \\
\text { others } \\
\text { Perceiving respect in } \\
\text { others } \\
\text { Perceiving optimism } \\
\text { in others } \\
\text { Perceiving thrill in } \\
\text { others } \\
\text { Perceiving hyperactiv- } \\
\text { ity in others } \\
\text { Perceiving excitement } \\
\text { in others } \\
\text { Perceiving rage in } \\
\text { others } \\
\text { Perceiving fatigue in } \\
\text { others } \\
\text { Perceiving fulfillment } \\
\text { in others } \\
\text { Perceiving mortifica- } \\
\text { tion in others } \\
\text { Perceiving joy in oth- } \\
\text { ers } \\
\text { Perceiving inspiration } \\
\text { in others } \\
\text { Perceiving surprise in } \\
\text { otheiving anxiety in } \\
\text { others } \\
\text { Perceiving mothide in } \\
\text { feelings } \\
\text { Understanding suthers } \\
\text { ing in others } \\
\text { Taking action that } \\
\text { helps others } \\
\text { in others } \\
\text { others } \\
\text { Percing }\end{array}$ & $\begin{array}{l}\text { Open Codes: } \\
\text { Compassionate em- } \\
\text { pathy } \\
\text { Cognitive empathy } \\
\text { Emotional empathy } \\
\text { Taking action to help } \\
\text { myself } \\
\text { Managing frustration } \\
\text { in myself }\end{array}$ & $\begin{array}{l}\text { Compassionate em- } \\
\text { pathy } \\
\text { Cognitive empathy } \\
\text { Emotional empathy } \\
\text { Taking action to help } \\
\text { myself } \\
\text { Managing frustration } \\
\text { in myself }\end{array}$ \\
\hline
\end{tabular}




\section{Validity of Qualitative Research}

In order to achieve standards for validating qualitative work, the following strategies were used: (1) member checking, (2) following data analysis by meeting with my participants; (3) external evaluation for consensus on codes, (4) peer review and (5) reading of my paper by professionals. Additionally, for qualitative purposes, the data and sources were triangulated: (1) data work products, (2) teacher interview, and (3) research observation. The sources were: teacher, researchers, parents, children, and kindergarten teachers. Quantitative data was gathered that supports the qualitative data.

\section{DISCUSSION}

The main findings of this research indicate that (1) the preschoolers demonstrated growth in the development of empathy and (2) the teachers also demonstrated the development of empathy in themselves. The findings also indicated (3) a possible change in the traditional discipline system commonly used in today's classroom, with a more innovative and constructive method that might potentially decrease negative behaviors in children with behavioral challenges.

Another finding that emerged from the teachers' reflection was the value of respect. In order to develop a culture of empathy, teachers modeled respectful behavior by carefully listening to children when they were attempting to express their ideas or feelings. Lastly, the kindergarten teacher's interview revealed that the students involved in this study were different. They were more aware of their surroundings and of the needs of the other children in the classroom. They were more connected and sensitive to the feelings and needs of others.

One of the findings revealed from the teachers' interviews was the positive change in the parents' self-worth, especially in those whose children were behaviorally and developmentally challenged. According to two teachers, at the beginning of the year, these parents appeared emotionally disconnected from their children because they were overwhelmed and had lost hope in their childrens' optimal development. They described their children as temperamental and manipulative, and lacking in any positive qualities. These parents also felt they lacked support from close family members and any school and teachers they had worked with in the past. The frustration was evident, and the feeling of being ashamed of their child and the negative behavior had caused this disconnect, leaving almost without the essential social and emotional attachment children need to establish with their parents or caregivers in the early years for the typical development of children. These parents would simply drop their children off at school then leave immediately, without participating in any school functions, because they were probably felt judged by the teachers, administrators and other parents, for the behavior of their child. This perception is very common in parents with children with 
challenging behaviors who lack support from their family and community. By the end of the academic year, the same teachers noticed a drastic change in these perceptions.

\section{LIMITATIONS AND IMPLICATIONS}

A limitation of this study is the absence of a control group to compare the data collected. Another is the small number of participants. An important implication for this study is a possible change in the traditional discipline system commonly used in today's classroom, with a more innovative and constructive method that might potentially decrease negative behaviors in children with behavioral challenges. This approach would focus more on emotions and less on rules and consequences. Other implications for future studies could be to increase the number of participants and/or to conduct a longitudinal study with infants and toddlers.

\section{CONCLUSION}

Educators need to be more consistent when developing a culture of empathy, and nurturing Emotional Intelligence in young children, which is essential for decreasing behavioral challenges and increasing self-regulation. Fostering empathy in young children should be something that is implemented and modeled daily, starting with ourselves, the families, and others in the community. Also, by building emotions and emotional literacy into the school curriculum, making it an integral part of the daily routines, empathy is more likely to become a vehicle used by the students to demonstrate to care for themselves and others, making it a useful tool for reducing behavioral challenges and problems in the classroom.

\section{GLOSSARY}

Atelierista: a teacher who is specialized in expressive arts and works directly with the other teachers

Emotional Intelligence: The perception and understanding of one's emotions and the emotions of others

Empathy: Being able to identify and manage feelings in others without expecting anything on return.

Global competence: The capacity and willingness to see oneself as part of the world; therefore, willing to be involved in solving problems of global significance and making the world a better place. 
Blythe, T., Allen, D., \& Powell, B. S. (2008). Looking together at student work. New York: Teachers College Press

Boix Mansilla, V., and Jackson, A. (2011). Educating for global competence: Preparing our youth to engage the world. New York: Asia Society.

Creswell, J. W. (2007). Qualitative inquiry and research design: Choosing among five approaches ( $2^{\text {nd }}$ ed.). Thousands Oaks, CA: Sage.

Creswell, J. W. (2012). Educational research: Planning, conducting, and evaluating quantitative and qualitative research (4th ed.). Upper Saddle River, NJ: Pearson.

Darling-Hammond, L. (2010). The flat world and education: How America's commitment to equity will determine our future. New York: Teacher College Press

Gangotena, V. Personal communication, December 15, 2015.

Gardner, H. \& Davis, K. (2013). The App Generation. New Haven: Yale University Press.

Goleman, D. (1995). Emotional intelligence: Why it can matter more than IQ. Bantam: New York.

Goleman, D. (2006) Social Intelligence: Beyong IQ, beyong Emotional Intelligence. New York, NY: Bantam Dell.

Harry, B., Sturges, K., \& Klinger, J. (2005). Mapping the process: An exemplar of process and challenge in grounded theory analysis. Educational Researcher, 34, 3-13.

Immordino-Yang, M.H., \& Damasio, A.R. (2007). We feel, therefore we learn: The relevance of affective and social neuroscience to education. Jossey-Bass Reader on the Brain and Learning (pp.183-198). San Francisco, CA: Jossey-Bass.

Mayer, T. \& Ulich, M. (2009). Social-emotional well-being and resilience of children in early childhood settings -PERIK: An empirically based observation scale for practitioners. Early years, 29(1) 45-57.

Noddings, N. (2005, September). What does it mean to educate the whole child? Educational Leadership (Alexandria, VA: Association for Supervision and Curriculum Development) 63 (1), 8-13.

Rieffe, C., Ketelaar, L., \& Wiefferink, C.H. (2010). Assessing empathy in young children; construction and validation of an empathy questionnaire (EmQue). Personality and Individual Differences, 49, 362-367.

Ritchhart, R., Church, M., Morrison, K. (2011). Making thinking visible: How to promote engagement, understanding, and independence for all learners. San Francisco Jossey-Bass Publishers.

Ritchhart, R. (2012). Creating Cultures of Thinking: The 8 Forces We Must Master to Truly Transform Our Schools. 
Salovey, P. Brackett, M., \& Mayer, J. (2004). Emotional intelligence: Key readings on the Mayer and Salovey Model. Port Chester, NY: Dude Publishing

Strauss, A., \& Corbin, J. (1998). Basics of qualitative research: Techniques and procedures for developing grounded theory (2nd ed.). Thousand Oaks, CA: Sage.

Vygotsky, Lev (1978). Mind in Society. London: Harvard University Press.

Whitehead, J., \& McNiff, J. (2006). Action research: Living theory. London: Sage 